Article

\title{
Indicators for Assessing Habitat Values and Pressures for Protected Areas-An Integrated Habitat and Land Cover Change Approach for the Udzungwa Mountains National Park in Tanzania
}

\author{
Andreas B. Brink 1,* , Javier Martínez-López ${ }^{1,2}$, Zoltan Szantoi ${ }^{1}$, Pablo Moreno-Atencia ${ }^{1}$, \\ Andrea Lupi ${ }^{1}$, Lucy Bastin ${ }^{1}$ and Grégoire Dubois ${ }^{1}$ \\ 1 European Commission Joint Research Centre, Directorate for Sustainable Resources, 21027 Ispra, Italy; \\ javier.martinez@bc3research.org (J.M.-L.); zoltan.szantoi@jrc.ec.europa.eu (Z.S.); \\ pablom_geo@hotmail.com (P.M.-A.); andrea.lupi@ext.jrc.ec.europa.eu (A.L.); \\ lucy.bastin@jrc.ec.europa.eu (L.B.); gregoire.dubois@jrc.ec.europa.eu (G.D.) \\ 2 BC3-Basque Centre for Climate Change, Sede Building 1, 1st Floor, \\ Scientific Campus of the University of the Basque Country, 48940 Leioa, Spain \\ * Correspondence: andreas.brink@jrc.ec.europa.eu; Tel.: +39-0332-785-567
}

Academic Editors: Parth Sarathi Roy and Prasad S. Thenkabail Received: 27 May 2016; Accepted: 11 October 2016; Published: 19 October 2016

\begin{abstract}
Assessing the status and monitoring the trends of land cover dynamics in and around protected areas is of utmost importance for park managers and decision makers. Moreover, to support the Convention on Biological Diversity (CBD)'s Strategic Action Plan including the Aichi Biodiversity Targets, such efforts are necessary to set a framework to reach the agreed national, regional or global targets. The integration of land use/cover change (LULCC) data with information on habitats and population density provides the means to assess potential degradation and disturbance resulting from anthropogenic activities such as agriculture and urban area expansion. This study assesses the LULCC over a 20 year (1990-2000-2010) period using freely available Landsat imagery and a dedicated method and toolbox for the Udzungwa Mountains National Park (UMNP) and its surroundings (20 km buffer) in Tanzania. Habitat data gathered from the Digital Observatory for Protected Areas (DOPA)'s eHabitat+ Web service were used to perform ecological stratification of the study area and to develop similarity maps of the potential presence of comparable habitat types outside the protected area. Finally, integration of the habitat similarity maps with the LULCC data was applied in order to evaluate potential pressures on the different habitats within the national park and on the linking corridors between UMNP and other protected areas in the context of wildlife movement and migration. The results show that the UMNP has not suffered from relevant human activities during the study period. The natural vegetation area has remained stable around $1780 \mathrm{~km}^{2}$. In the surrounding $20 \mathrm{~km}$ buffer area and the connecting corridors, however, the anthropogenic impact has been strong. Artificially built up areas increased by $14.24 \%$ over the last 20 years and the agriculture area increased from $11 \%$ in 1990 to 30\% in the year 2010. The habitat functional types and the similarity maps confirmed the importance of the buffer zone and the connecting corridors for wildlife movements, while the similarity maps detected other potential corridors for wildlife.
\end{abstract}

Keywords: land cover; habitats; Tanzania; Udzungwa; DOPA; BIOPAMA; SAGCOT

\section{Introduction}

Protected Areas (PAs) are essential for conserving biodiversity and are our main hope for meeting ambitious global conservation targets, such as preventing species extinctions [1]. However, in order to sustain biodiversity, PA's need to be managed as a coherent network rather than isolated habitat islands, 
particularly in the face of climate change [2]. Isolation of natural areas, protected or non-protected, is the first step towards fragmentation of habitats, the destruction of ecosystems and consequent loss of biodiversity [2].

PAs need to be assessed systematically according to biodiversity values and threats in order to support decision making and fund allocation processes [3]. Characterizing PAs according to their species assemblages, ecosystem type, and threats posed to them is therefore crucial. While species-based conservation approaches are the most commonly used, assessment of natural habitats is also important. Among other ecosystem services, natural habitats offer refuge for species and can be mapped on a global scale in a harmonized way by means of remote sensing, which is less biased by sampling efforts related to study location or taxa [4].

The Democratic Republic of Tanzania (hereafter "Tanzania") ranks among the top five biologically rich countries in Africa [5,6]. The role and importance of the country's biological diversity and richness-both from a conservation point of view and from a social and economic perspective-is highly recognized by the Tanzanian government, proven by the fact that, proportionately, Tanzania has one of the highest land surface areas devoted to resource conservation (28\%) compared to other countries worldwide [7]. However, this area under protection does not include the critically important wildlife corridors (here defined as an area with no legally protected status between two or more PA's) which ensure animal movements and migration and help to maintain genetic variation among protected species. In fact, a 2009 assessment on wildlife corridors in Tanzania reported that the 31 major corridors in the country are under severe threat [8]; a later assessment which focused on monitoring corridor functions confirmed the loss of some corridors [9-11].

Urbanization, infrastructure development and agriculture practices are the main anthropogenic activities on the land and represent the main pressures on PAs and their connecting corridors. Population increased nearly exponentially in Tanzania in the last decades, increasing from around 12 million inhabitants in 1967 to 38 million in 2005 and 49 million in 2013 [12]. In order to react to the increasing population needs and the competing human and ecosystem services, in 2011 the government of Tanzania developed a "Greenprint" for accelerating sustainable agricultural development in the SAGCOT (Southern Agricultural Growth Corridor of Tanzania) region. The defined area extends from the Indian Ocean to the Zambian border. This initiative incorporates the needs of smallholder farmers to embrace modern technologies and management systems in order to produce "Agriculture Green Growth" to sustainably intensify agriculture, while simultaneously conserving natural resources to reduce pressures on forest, water and biodiversity [13].

The need to monitor the different habitats and the associated species diversity in and around PAs is an essential component of conservation and effective PA management, as it allows managers to identify and assess problems, prioritize and develop solutions and use resources effectively [14]. Geospatial data and remote sensing images especially have been identified as key solutions for monitoring of sites since satellite data have the capability to capture information at various spatial, spectral, and temporal scales across extensive areas in an objective and repeatable manner. In particular, LULCC as assessed from remote sensing, is one of the most evident and detectable indicators of land surface characteristics. Monitoring LULCC over time provides important information on issues such as compliance with land management schemes, predicting threats to biodiversity and PAs from shifting human population distribution and changes in agricultural practices. Another benefit of remote sensing is its capacity to support quantification of possible fragmentation and loss of remaining habitats, and calculation of economic metrics such as carbon storage [15].

The aim of this paper is to study the potential impact of development projects such as the SAGCOT initiative on the Udzungwa Mountains National Park (UMNP) and its surrounding buffer zone (20 km) with particular attention to the wildlife corridors which connect the PA to other conservation areas [16]. This was addressed in three ways: (1) application of an existing methodology to identify habitats and existing ecologically similar areas outside the UMNP, which are potentially useful for wildlife and their movements $[17,18]$; (2) assessment of the impact of human activities over time through land use/land cover (LULC) conversions inside the UMNP and especially in the surroundings, including 
non-protected areas and defined wildlife corridors through the analysis of satellite image time series [19]; (3) integration of the habitat similarity maps with the LULCC data to detect anthropogenic pressure caused by agriculture and urbanization to existing corridors and potentially new corridors. The importance and uniqueness of this study lies in the combination of existing methods and tools to automatize the identification of habitats with potentially high biodiversity and the assessment of pressures to these. This was accomplished by combining datasets that measure human activities (i.e., urban uses, agricultural uses) and their impacts (i.e., deforestation, loss of natural vegetation) with ecological, climatic and geographic datasets. The integration of the presented methods for the specific case study in the UMNP can potentially be replicated over any PA in the world.

\section{Methodology}

\subsection{Study Area}

The Southern Agricultural Growth Corridor [13] covers approximately one-third of mainland Tanzania. It extends north and south of the central rail, road and power 'backbone' that runs from Dar Es Salaam to the northern areas of Zambia and Malawi. (Figure 1 small insert). The SAGCOT involves three key development clusters, Kilombero, Ihemi and Mbarali (shown as ellipse within the SAGCOT area in the Figure 1 insert), which are defined by their great agricultural potential, extensive forests, wildlife, PAs and also their high levels of poverty [13]. This paper focuses on the Kilombero cluster, which is located between two important PAs, the Udzungwa Mountains National Park in the north and the Selous Game Reserve in the southeast separated by the Kilombero Valley Floodplain.

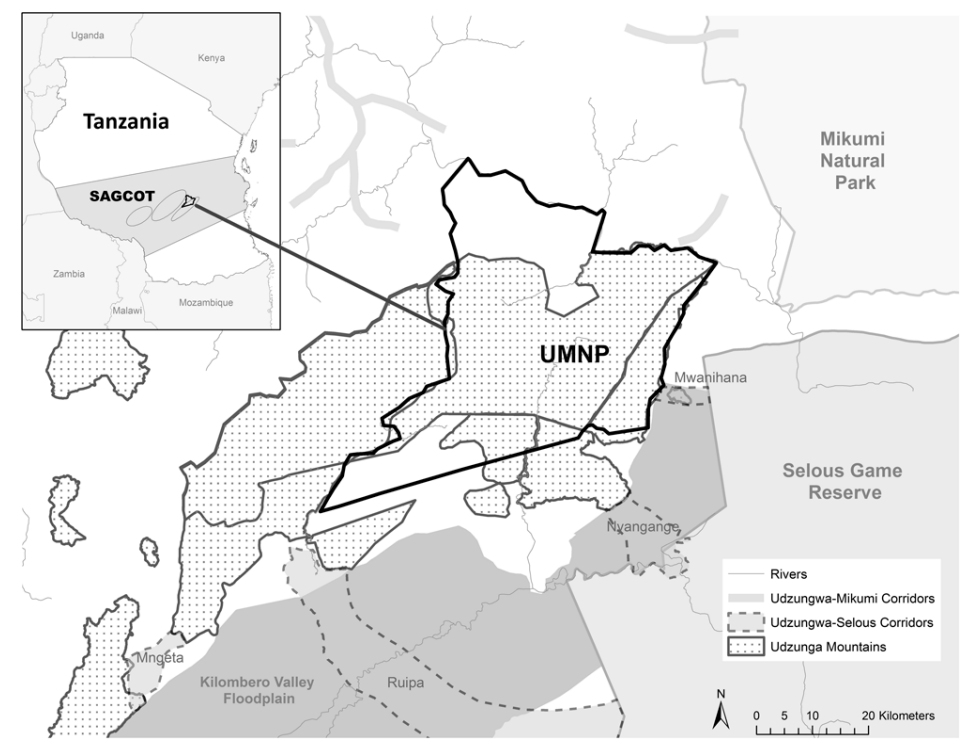

Figure 1. Udzungwa Mountains National Park (UMNP), Protected Areas (PAs) around and wildlife corridors connecting to the UMNP. Insert: Location of the UMNP within the Development Clusters (shown as ellipse) in the SAGCOT area in Tanzania. The Kilombero cluster is the most southern ellipse.

The Kilombero Valley Floodplain is part of the Kilombero development cluster representing an ideal area for large scale paddy rice and sugarcane production due to the seasonal flooding and the potential for large scale irrigation schemes. Nowadays, more than $50 \%$ of the valley is cultivated, of which $77 \%$ is cultivated by large scale farmers and only $23 \%$ by smallholders [13].

The UMNP has a size of $1990 \mathrm{~km}^{2}$ [20] and is within the Udzungwa Mountains $\left(>12,000 \mathrm{~km}^{2}\right)$, which are part of the Eastern Arc (Figure 1). The UMNP was declared as a national park in 1992 because of its unique habitat, including the largest forest blocks with the largest altitudinal gradient of continuous forest from the Kilombero Valley at $250 \mathrm{~m}$ above sea level to the highest ridges above $2000 \mathrm{~m}$. The climate is variable, with rainfall being as high as $2000-3000 \mathrm{~mm}$ per year on the eastern sides of 
moist forest blocks, and as low as $500 \mathrm{~mm}$ per year on drier slopes. The temperature ranges from a minimum of 21 degrees Celsius in July to a maximum of 31 degrees Celsius in October [21]. This area lies at the boundary between three ecoregions [22]: (1) the Eastern Miombo woodlands, composed by tropical and subtropical grassland, savanna and shrubland; (2) the Northern Zanzibar-Inhambane coastal forest mosaic, composed by tropical and subtropical moist broadleaf forests and (3) the Eastern Arc Forest composed by tropical and subtropical moist broadleaf forests.

The PA harbors more than 500 bird species, 159 mammals and 2500 plant species (25\% of which are endemic) [23]. Of the six primate species five are endemic and two are unique to the Udzungwa Mountains, the Udzungwa red colobus (Procolobus gordonorum) and the Sanje mangabey (Cercocebus sanjei) [24]. Both of the latter species are endangered according to the IUCN Red List [25]. For more details on local species composition, habitats, climate and pressures, we refer to the site assessment depicted in the Digital Observatory for Protected Areas (DOPA) Explorer 1.0. [7].

The UMNP connects to the neighboring Selous Game Reserve (Figure 1), which hosts the largest population of elephants in East Africa, through one of the most productive and ecologically important wetlands in Tanzania, the Kilombero Valley Floodplain, declared as RAMSAR in 2002 (RAMSAR, the Convention on Wetlands, also called the Ramsar Convention, is the intergovernmental treaty that provides the framework for the conservation and wise use of wetlands and their resources) [26]. Wildlife corridors between these areas (Figure 1) have been documented for decades by the local population and by scientific studies [8] including the two corridors analyzed in this study - the Ruipa and Nyangange corridors. These corridors are mainly used by large mammals such as elephant (Loxodonta Africana), buffalo (Syncerus caffer), bushbuck (Tragelaphus scriptus) or Harvey's duiker (Cephalophus harveyi) among others [27]. The third most northern corridor visible in Figure 1-the Mwanihana corridor-was not included in the assessment due to heavy cloud coverage in the images over this specific area.

\subsection{Processing Steps and Working Environment}

As a first step the eHabitat+ module within the DOPA was applied to perform ecological stratification of the study area and to gather habitat data. From this, similarity maps of the potential presence of comparable habitat types outside the protected area were developed. The second step included the generation of LULCC maps inside the national park and the surrounding buffer by applying the satellite IMagery ProCessing Toolbox (v1.2b, IMPACT) [19,28]. Finally, the habitat similarity maps were integrated with the LULCC data in order to evaluate potential pressures on the different habitats within the national park and on the linking corridors between UMNP and other PAs in the context of wildlife movement and migration. The different steps are described in Figure 2 and a link to the tools is provided in Appendix A.

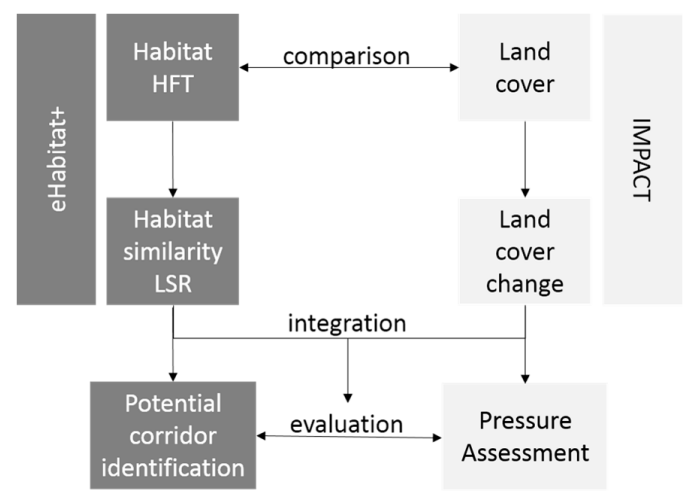

Figure 2. Processing steps including Habitat Functional Types (HFT), Landscape Similarity Maps and Ratios (LSR), land use/land cover (LULC) and land use/cover change (LULCC) assessment. The two processing environments (eHabitat+ and IMPACT) are highlighted in dark and light grey respectively. 


\subsection{Habitat Functional Types (HFT)}

PAs are composed of heterogeneous landscapes containing different habitat functional types that need to be identified for assessing structural (e.g., vegetation type) and functional (e.g., vegetation phenology based on time series of NDVI) ecosystem properties [29]. In addition to the LULC maps obtained through the IMPACT toolbox, eHabitat+ was used to investigate the presence of different functional habitat types in this PA, based on a quantitative biophysical approach [17,30].

eHabitat+ first performs an automatic landscape segmentation inside a selected PA, using 9 environmental variables, some of them representing long term annual averages and all of them mapped at $1 \mathrm{~km}^{2}$ globally: percentage of tree and percentage of grassland cover [31], slope [32], aridity, biotemperature (temperature excluding below zero values) and precipitation [33], Normalized Difference Vegetation index (NDVI Max. and Min.) [34,35] and Normalized Difference Water index (NDWI) [36,37]. The automatic segmentation procedure is based on a region growing algorithm and requires two main parameters: a minimum patch size and a similarity threshold [38]. The similarity threshold, ranging from 0 to 1 , was automatically set based on optimal autocorrelation and variance values among the segments and the minimum patch size was set to be the square root of the total area containing the park to avoid obtaining segment sizes that were too small to represent any manageable habitat functional types [18]. These automated procedures identified and mapped uniform biophysical conditions or habitat functional types (HFT) related to specific species and communities $[18,39]$.

In a second stage, each HFT identified in the park was processed independently to generate maps of similar areas computed over the entire area of the corresponding ecoregions defined by Olson et al. (2001). This process was based on the computation of the Mahalanobis distance value for each pixel of the ecoregion in relation to the reference area [40]. The average values of each HFT for all abovementioned study variables were therefore compared with their values in each pixel in the corresponding ecoregion, in order to get a continuous map of similarity. A Landscape Similarity Ratio (LSR) was computed for each HFT patch as following: similar patches were defined as continuous areas that present similarity values higher than the average value in the reference area and the LSR represented the total extent of similar areas outside the reference area, which were bigger or equal than the reference patch, divided by the extent of the reference HFT.

\subsection{Land Use and Land Cover Changes (LULCC)}

For this study the IMPACT toolbox was used. The toolbox includes pre and post image processing capabilities and combines automated processing chains with minimal user interaction [19]. Medium spatial resolution $(30 \mathrm{~m})$ Landsat TM and ETM+ satellite data were downloaded from the U.S. Geological Survey's (USGS) Earth Resources Observation and Science (EROS) Center (http:/ /glovis.usgs.gov) at $30 \mathrm{~m}$ spectral resolution over the UMNP study area including a $20 \mathrm{~km}$ buffer zone. To select the best imagery in terms of cloud cover and seasonal/radiometric characteristics, all available Landsat images were visually screened and pre-processed including the assessment and correction of spatial registration, cloud masking, conversion to top of atmosphere reflectance, haze correction, topographic correction and normalization or relative calibration [41,42]. To detect LULCC the exact surface reflectance is not always necessary [43] and in this study relative normalization was applied to adjust the spectral values of all images to the values of one reference image and hence set the radiometric measurements to a common relative scale. This ensures the spectral homogeneity of the multi-temporal data set. The approach relies on the capability to identify stable targets between dates (e.g., dense evergreen forest), named Pseudo-Invariant Features (PIF), and assumes that reflectance differences in these stable targets are due to atmospheric perturbations [44]. Finally, a simple linear relationship among images across time was used to normalize images to the same reference level. A detailed description of the approach is provided by Bodart et al. (2011). The six reflective spectral bands (1-5 and 7) of Landsat TM and ETM+ images were used for the pre-processing and the thermal infrared band (6) served for the cloud masking. Subsequently, a fully automated multi-date image segmentation and classification algorithm was employed to produce thematic LULC maps for the area. 
The image segmentation was done employing the Baazt segmenter [45] available in Inpe's TerraLib Operators [46]. The generated objects (polygons) were automatically labelled according to a class majority derived from a pixel based classification [42]. For the purpose of LULCC assessment the multi-date segmentation approach was preferred to two separate, single-date image segmentations, since it integrates from the very beginning the temporal aspect into the generation of spatially and spectrally consistent mapping units, reducing extra processing effort for delineating change polygons [47]. The IMPACT toolbox not only includes all these various processing steps, but also allows the user to interact, verify and correct in real time the thematic maps in a manual visual interpretation modus. The LULC classes assigned by the automated classification algorithm included tree cover, tree cover mosaic, other wooded land (shrubs), other land cover (agriculture, natural herbaceous, bare areas and urban), water, and clouds and cloud shadows. In the manual verification step, the method allows the segments classified as other land cover to be further discriminated into agriculture and urban land use and other land cover (natural herbaceous and bare areas) classes. The classes were defined in the framework of the JRC TREES-3 project, as shown in Table 1.

Table 1. Land cover classification definition classes.

\begin{tabular}{ll}
\hline Class & Description \\
\hline Tree cover & $\begin{array}{l}\text { At least } 70 \% \text { or more of the segment area corresponds to a continuous } \\
\text { layer of trees; canopy density at least } 10 \% \text {; tree height } \geq 5 \mathrm{~m}\end{array}$ \\
\hline Tree cover mosaic & $\begin{array}{l}\text { Total area of tree cover in a segment ranges between } 30 \% \text { and } 70 \% ; \\
\text { canopy density at least } 10 \% \text {; tree height } \geq 5 \mathrm{~m}\end{array}$ \\
\hline Other wooded land/shrub cover & $\begin{array}{l}\text { At least } 70 \% \text { or more of the segment area should display to a continuous } \\
\text { layer of 'shrubs' }\end{array}$ \\
\hline Agriculture & $\begin{array}{l}\text { At least } 70 \% \text { or more of the segment area should display to a continuous } \\
\text { layer of 'agriculture' }\end{array}$ \\
\hline Other land cover & $\begin{array}{l}\text { Contains land cover other than tree and shrub cover (e.g., herbaceous } \\
\text { vegetation cover, lichens and mosses, bare land, artificial surfaces) }\end{array}$ \\
\hline Urban & Artificial and urban areas \\
\hline
\end{tabular}

Single year LULC maps were produced for the three investigated years (1990, 2000 and 2010) and LULCC were assessed for the decades of 1990-2000 and 2000-2010 as percentage and area $\left(\mathrm{km}^{2}\right)$ changes. Subsequently, the monitored change indicators emphasize the loss of natural vegetation (such as deforestation and forest degradation and wood- and shrubland clearing) and agriculture and urban area encroachment and expansion inside and outside of the PA. In addition, specific attention was given to the Udzungwa-Selous corridors; LULC dynamics for these corridors were measured separately in order to estimate the pressure from anthropogenic sources not only on the UMNP, but also on the connecting corridors between neighboring PAs.

A variety of ancillary geospatial datasets were collected to complement the above information, including infrastructure, administrative boundaries, species composition and other existent land cover inventories, as well as national statistics related to human population (Tanzania official census) or wildlife inventories (Tanzania Wildlife Conservation Monitoring).

The National Bureau of Statistics of Tanzania provided the regional, district, ward and street map references. For PAs, polygon boundaries for the Udzungwa Mountains National Park and all the PAs around the National Park were obtained from the World Database on Protected Areas (WDPA) through its online interface ProtectedPlanet.net [20]. Updated infrastructures such as railroads, roads and settlements have been taken from the OpenStreetMap database [48]. 


\section{Results}

\subsection{Land Use/Land Cover and Habitats in the UMNP}

Forest areas are the principal landscape type in the UMNP. The results from the produced LULC map indicate that around $45 \%$ of the park is covered by primary closed-canopy forests (broadleaved evergreen) as of 2010. Mosaics of tree cover, mostly broadleaved deciduous and shrublands, are also common, covering around $24 \%$ and $23 \%$ respectively. These mosaics extend in the park around the forest patches (see Figure 3).

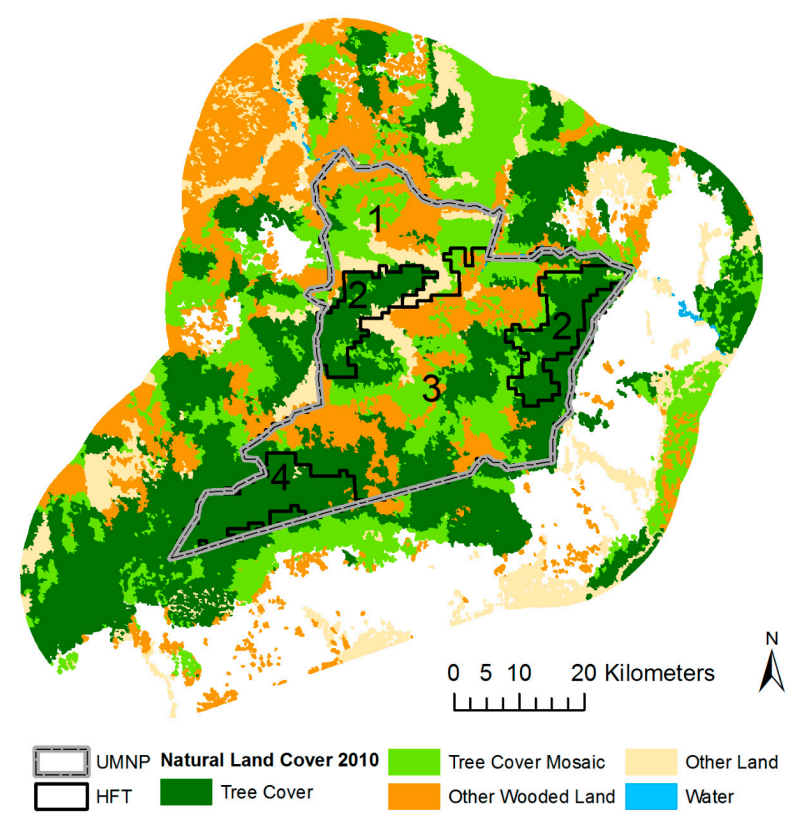

Figure 3. Map of Habitat Functional Type (HFT) clusters obtained in the PA overlaid with the LULC map representing natural vegetation only. The areas in white symbolize non natural vegetation (e.g., agriculture).

In total, around $93 \%$ of the UMNP is covered by natural areas that provide a number of different habitats like mountain forest, Miombo woodland and patches of grassland as described by the four different HFTs identified by the proposed methodology. HFT 1 represents a well-defined area characterized by medium slope and biotemperature, high aridity and the lowest precipitation in all HFTs of the PA. It is located in the northern part of the park and shows the lowest percentage of tree cover of all HFTs and a predominance of grassland. This is in accordance with the higher resolution LULC map which identified also very little tree cover in this area, with a dominance of wood and shrublands, tree cover mosaic and grassland. HFT 2 is represented by two distinct clusters describing the mountain forest, which match accurately the LULC map showing two well defined dense tree cover areas. The radar plot of Figure 4 shows the highest slope of all segments, medium NDWI values and a dominance of tree with some grassland vegetation cover. HFT 3 is the largest of all clusters as shown in Table 2 , representing a heterogeneous and mixed vegetation habitat with high NDWI values and relative high values for all other biophysical variables. The vegetation cover is characterized by a mixture of high grassland and tree cover. In addition, the LULC map shows for this large cluster an area with mixed LULC including tree cover, tree cover mosaic, wood and shrubland and grassland. However the higher resolution LULC data is able to discriminate and classify with greater accuracy this area. HFT 4 is located in the southwestern end of the PA and is distinguished by the lowest slope value of all HFTs. However for most other biophysical variables such as NDVI_MIN, NDVI_MAX, NDWI, biotemperature, Precipitation and Aridity, this category shows the highest values 
of all segments and the vegetation cover verifies that it has the highest value for tree cover. HFT 4 is again an accurately identified cluster and compares well to the LULC map which shows high tree cover. However, according to the HFT map, the forest ecosystem of this area has substantially different biophysical characteristics from the forest ecosystem of HFT 2 (Figure 4). In general the identified four HFTs match well with those described in Struhsaker et al. (2004) [49] within the UMNP. Overall, the characterization of each HFT is in agreement with the results obtained from the independent land use/land cover (LULC) dataset during the study period (see Figure B1 in Appendix B).

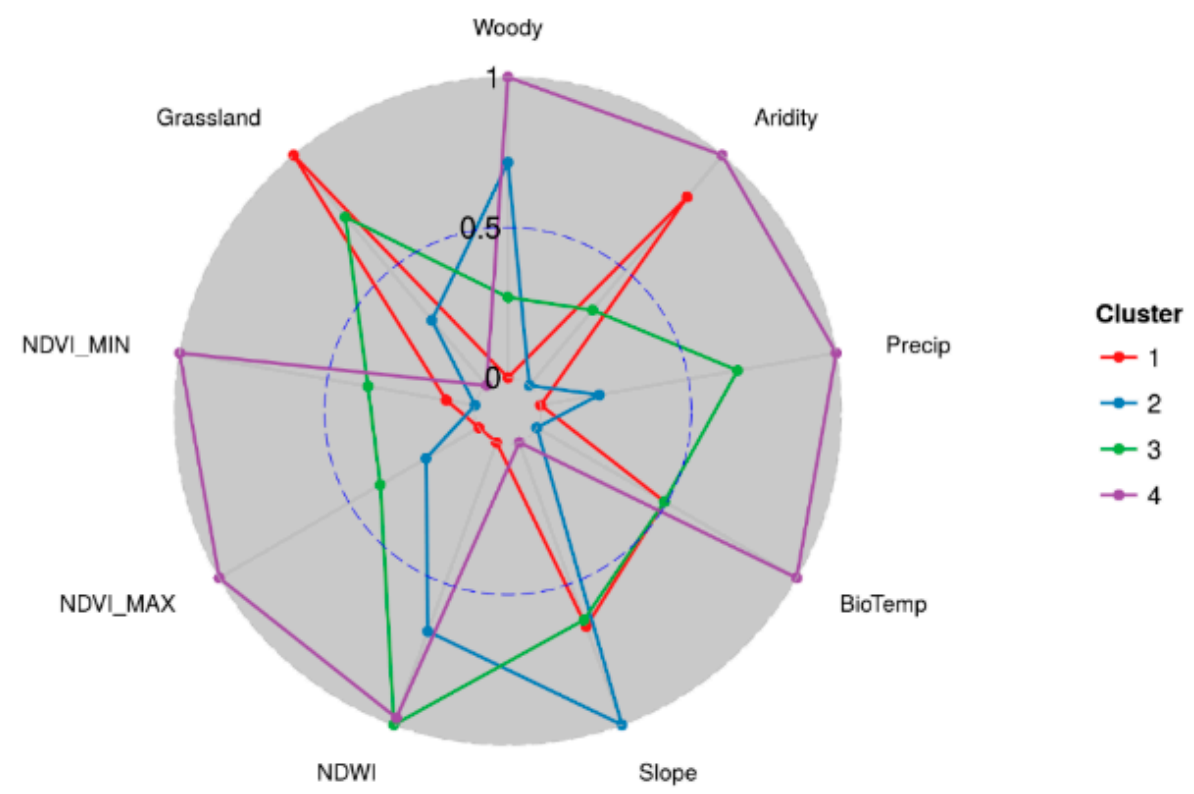

Figure 4. Normalized average values of the study variables in each HFT identified. Variables legend: percentage of tree (Woody) and grassland cover (Grassland), slope (Slope), aridity (Aridity), biotemperature (BioTemp), precipitation (Precip), Maximum and Minimum Normalized Difference Vegetation index (NDVI_MAX and NDVI_MIN, respectively) and Normalized Difference Water index (NDWI).

Table 2. HFT detected inside the PA; LSR: Landscape Similarity Ratio value for each segment; Number of similar areas to each HFT found outside the PA. Area of each HFT inside the PA.

\begin{tabular}{ccc}
\hline HFT & Number of Similar Functional Areas (LSR) & HFT Area $\mathbf{( k m}^{\mathbf{2}} \mathbf{~}$ \\
\hline 1 & 1.39 & 381 \\
2 & 0.7 & 288 \\
3 & 1.1 & 1089 \\
4 & 0.79 & 184 \\
\hline
\end{tabular}

The LULCC analysis demonstrates that the natural areas inside the park did not suffer reduction in the two decades up to 2010, remaining almost stable from $1778 \mathrm{~km}^{2}$ in 1990 to $1780 \mathrm{~km}^{2}$ in 2010 as shown in Table 3.

Table 3. LULC and evolution of land cover in the UMNP. $\mathrm{km}^{2}$ and $\%$ change.

\begin{tabular}{cccccc}
\hline Class & $\left.\mathbf{1 9 9 0} \mathbf{( k m}^{\mathbf{2}}\right)$ & $\left.\mathbf{2 0 0 0} \mathbf{( k m}^{\mathbf{2}}\right)$ & $\left.\mathbf{2 0 1 0} \mathbf{( k m}^{\mathbf{2}}\right)$ & $\mathbf{1 9 9 0 - 2 0 0 0} \mathbf{( \% )}$ & $\mathbf{2 0 0 0 - 2 0 1 0} \mathbf{( \% )}$ \\
\hline Tree Cover & 870.2 & 870.7 & 863.9 & 0.1 & -0.8 \\
Tree Cover Mosaic & 467.2 & 470.5 & 473.7 & 0.7 & 0.7 \\
Other Wooded Land & 441.4 & 440.1 & 442.6 & -0.3 & 0.6 \\
Water & 3.9 & 3.9 & 3.9 & No changes & No changes \\
Other Land & 122.8 & 121.4 & 121.9 & -1.1 & 0.5 \\
\hline
\end{tabular}




\subsection{Land Cover and Land Cover Changes in the $20 \mathrm{~km}$ Buffer around UMNP}

Artificial land in the $20 \mathrm{~km}$ buffer surrounding the PA has increased from $33.7 \mathrm{~km}^{2}$ to $38.5 \mathrm{~km}^{2}$ $(14.24 \%)$ in 20 years (Table 4). This urban area development stands in direct relation to the expansion and intensification of the crop area surrounding the UMNP. The agricultural land use represented only $11 \%$ of the total buffer area in 1990 , which increased to $30 \%$ by 2010 . This increase was faster in the first decade (124\%) than in the second decade $(18.1 \%)$.

Table 4. LULC in the buffer around UMNP. $\mathrm{km}^{2}$ and \% of variation between 1990-2000 and 2000-2010.

\begin{tabular}{cccccc}
\hline Class & $\mathbf{1 9 9 0} \mathbf{( k m}^{\mathbf{2}} \mathbf{)}$ & $\left.\mathbf{2 0 0 0} \mathbf{( k m}^{\mathbf{2}}\right)$ & $\left.\mathbf{2 0 1 0} \mathbf{( k m}^{\mathbf{2}}\right)$ & $\mathbf{1 9 9 0 - 2 0 0 0} \mathbf{( \% )}$ & $\mathbf{2 0 0 0 - 2 0 1 0} \mathbf{( \% )}$ \\
\hline Tree Cover & 1670.9 & 1565.2 & 1530.0 & -6.3 & -2.2 \\
Tree Cover Mosaic & 1256.1 & 1069.6 & 1018.4 & -14.8 & -4.8 \\
Other Wooded Land & 1537.7 & 1069.6 & 951.1 & -30.4 & -11.1 \\
Agriculture & 689.9 & 1545.5 & 1825.3 & 124 & 18.1 \\
Water & 16.4 & 15.8 & 15.4 & -3.7 & -2.8 \\
Other Land & 690.0 & 685.7 & 591.9 & -0.6 & -13.7 \\
Urban & 33.7 & 37.4 & 38.5 & 11 & 3 \\
\hline
\end{tabular}

Table 5 illustrates specifically how agricultural land has increased at the expense of natural vegetation. Other wooded land and shrublands, have diminished by $491.9 \mathrm{~km}^{2}$ in the first period ( $62.3 \%$ of this change is related to agricultural expansion) and by $146.1 \mathrm{~km}^{2}$ in the second period, mainly in the Kilombero Valley and driven by favorable crop conditions [13]. Tree cover mosaics have lost $173.5 \mathrm{~km}^{2}$ in the first period (93\% of which was caused by agricultural changes) and $56.4 \mathrm{~km}^{2}$ in the second period, mostly in the closest surroundings to forest reserves. Tree cover has also been converted to agriculture, about $40.8 \mathrm{~km}^{2}$ in the first decade and about $15.9 \mathrm{~km}^{2}$ in the second decade and the remaining other land cover class, predominantly natural grasslands, has been reduced by $83.7 \mathrm{~km}^{2}$ and $83 \mathrm{~km}^{2}$ in the first and second period respectively.

Table 5. Agricultural land cover changes in the buffer around UMNP. $\mathrm{km}^{2}$ and \% of total agricultural change.

\begin{tabular}{ccccc}
\hline Class & $\left.\mathbf{1 9 9 0 - 2 0 0 0 ~} \mathbf{( k m}^{\mathbf{2}}\right)$ & $\mathbf{2 0 0 0 - \mathbf { 2 0 1 0 }} \mathbf{( \mathbf { k m } ^ { \mathbf { 2 } } )}$ & $\mathbf{1 9 9 0 - 2 0 0 0} \mathbf{( \% )}$ & $\mathbf{2 0 0 0 - 2 0 1 0} \mathbf{( \% )}$ \\
\hline Tree Cover to Agriculture & 40.8 & 15.9 & 5.2 & 5.3 \\
Tree Cover Mosaic to Agriculture & 173.5 & 56.4 & 22 & 18.7 \\
Other Wooded Land to & 491.9 & 146.1 & 62.3 & 48.5 \\
Agriculture & 83.7 & 83 & 10.6 & 27.5 \\
Other Land to Agriculture & & & \\
\hline
\end{tabular}

Overall the natural vegetation (tree cover, tree cover mosaic, other woodland/shrubland and other land) in the UMNP $20 \mathrm{~km}$ buffer zone represented 74\% in 1990 which was reduced to $58 \%$ in 2010. This means that $21.6 \%$ of natural vegetation has been lost over the studied 20 year time period, corresponding to a total loss of over $1091 \mathrm{~km}^{2}$. These changes were predominantly located in the southern part of the buffer, especially along the fertile soils of the Kilombero Valley Floodplain, as evidenced in Figure 5. 


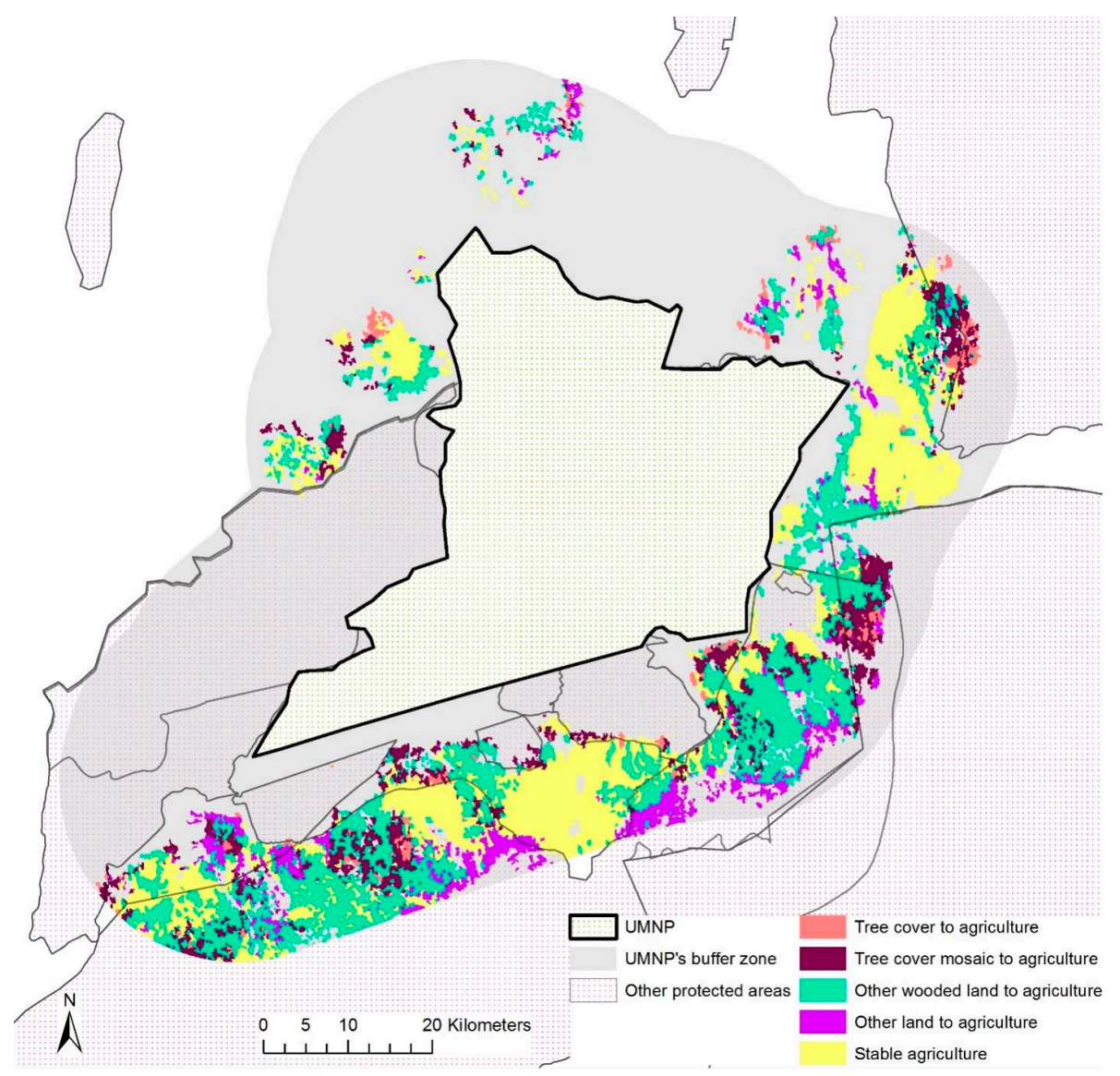

Figure 5. Agricultural Land cover changes 1990-2010 within the $20 \mathrm{~km}^{2}$ buffer zone.

\subsection{Land Use and Land Cover Changes in the Udzungwa-Selous Corridors}

Urban development does not exist inside the Ruipa and Nyangange corridors, but development was observed along the principal road and railroad (Tanzania-Zambia Railway Authority, TAZARA). Population has nearly doubled in this area in the last decade: for example, in the biggest settlement close to the Ruipa corridor, population rose from 13,541 inhabitants in 2002 to 22,717 in 2012. For the Nyangange corridor, the surrounding villages had a major population increase from 2002 to 2012 of $45 \%$ [50].

The increase in agricultural area is most evident in the Ruipa corridor. Major agricultural development has taken place in the floodplain of the Kilombero Valley (buffer area), increasing from $16.4 \%$ in 1990 to $75.2 \%$ in 2010 . The natural vegetation classes which predominantly changed to agriculture, in descending order, were other wooded land and shrub lands, followed by other land cover (mainly grasslands), tree cover mosaic and to a lesser extent tree cover (see Table 6 and Figure 6a). In total, $73.4 \mathrm{~km}^{2}$ of natural vegetation has been converted to agriculture in the studied 20 year time frame in the Ruipa wildlife corridor.

The Nyangange corridor has been less altered by agricultural development. The principal changes occurred in the other wooded land class, followed by other land cover and to a minor extend the tree cover mosaic class (Table 6 and Figure 6b). From the total area of natural vegetation in $199072.2 \mathrm{~km}^{2}$, corresponding to $44.59 \%$, had been converted to agriculture in 2010 . 
Table 6. Agricultural changes from natural areas in the Ruipa and Nyangange corridor. $\mathrm{km}^{2}$ and \% from the total of agricultural changes.

\begin{tabular}{|c|c|c|c|c|}
\hline Indicators & $1990-2000\left(\mathrm{~km}^{2}\right)$ & $2000-2010\left(\mathrm{~km}^{2}\right)$ & 1990-2000 (\%) & $2000-2010(\%)$ \\
\hline \multicolumn{5}{|l|}{ Ruipa corridor } \\
\hline Tree Cover to Agriculture & 0.5 & 1.3 & 1.2 & 2.9 \\
\hline Tree Cover Mosaic to Agriculture & 1.5 & 10.6 & 3.6 & 23.5 \\
\hline Other Wooded land to Agriculture & 29.6 & 17.7 & 70.3 & 39.2 \\
\hline Other Land to Agriculture & 10.5 & 15.6 & 24.9 & 34.5 \\
\hline \multicolumn{5}{|l|}{ Nyangange corridor } \\
\hline Tree Cover Mosaic to Agriculture & 1.6 & 0 & 6.1 & 0 \\
\hline Other Wooded land to Agriculture & 14.5 & 2.8 & 54.9 & 47.5 \\
\hline Other Land to Agriculture & 10.3 & 3.1 & 39 & 52.5 \\
\hline
\end{tabular}
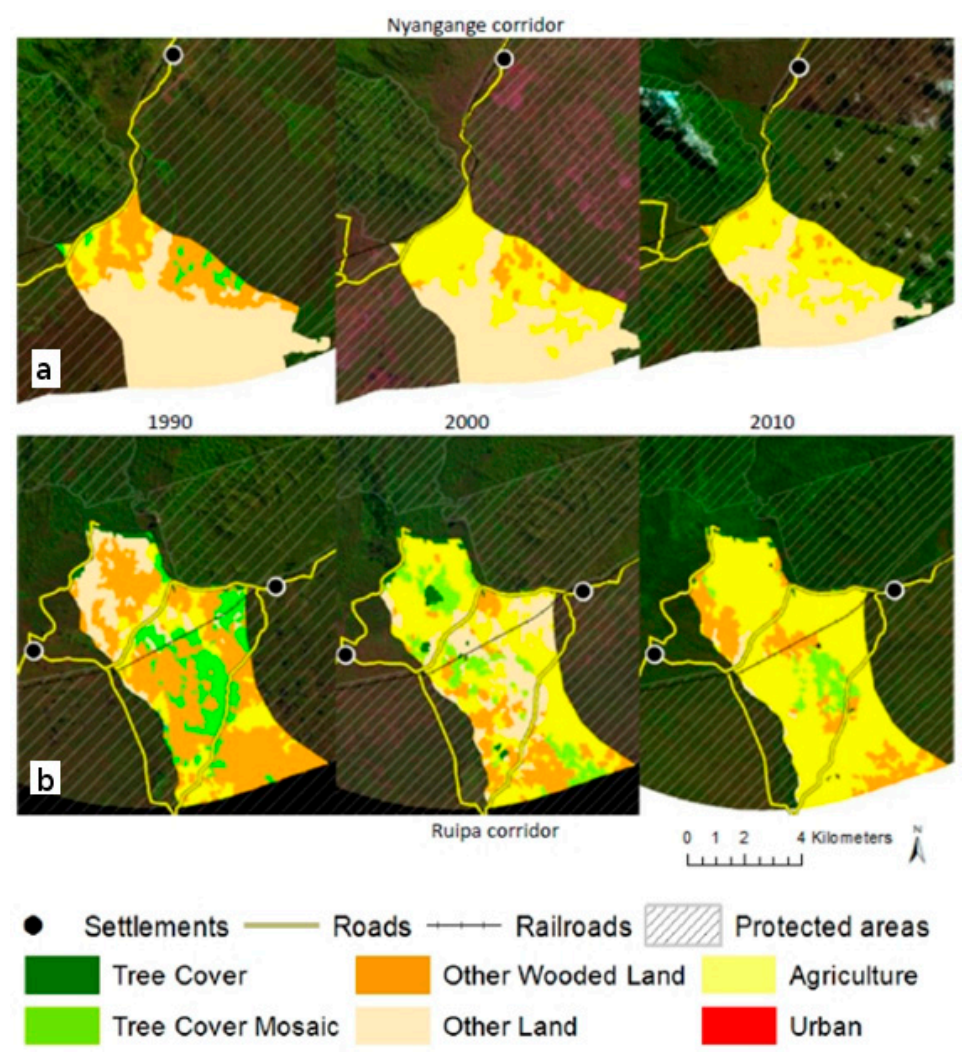

Figure 6. Land use/cover (LULC) evolution in the Nyangange (a) and Ruipa (b) corridors.

\subsection{Application of the Similarity and Land Use/Cover Change (LULCC) Maps for Mapping Animal Corridors}

The analysis of the similar areas of the HFT that were identified in this PA showed that three of them were strongly related to the presence of animal corridors around the PA. More precisely, the similarity map of HFT 1 shows a continuation towards the north and northeastern part of the park (Figure 7) connecting towards the Mikumi National Park and the Pala Mountain Forest Reserve. In addition, HFT 3, and, to some extent, HFT 2 show a high level of similarities in the northeastern areas, in the east side of the Great Ruaha River. The LULCC analysis indicates low rates of change, and little agricultural use in the last 20 years, perhaps because of the absence of railroads or a strong network of roads and settlements. With a high density of natural vegetation in all four natural vegetation classes, this landscape reproduces habitats of interest for wildlife species, such as elephants between UMNP and Mikumi Natural Park, through the Selous-Mikumi corridors [8]. Another area with a high level of similarities, is located in the southwestern area linking through the Mngeta Corridor, 
the UMNP and the Kilombero Nature Reserve with the Udzungwa Scarp Forest Reserve, one of the habitats where populations of Red Colobus have been documented [51] and are highly threatened because of the expansion of the saturated Kilombero Valley for farming [27]. This area is particularly well represented by HFT 2 as shown in Figure 7. HFT 3 represents the biggest segment in the park $\left(1089 \mathrm{~km}^{2}\right)$. It is a heterogeneous area characterized by a mixture of tree cover, tree cover mosaic and wood and shrubland and hence similar areas have been identified in a more scattered way, in particular bordering the Selous Reserve and following the mountain arc towards the southwest. In contrast to the other HFTs, HFT 4 which is the smallest of all segments with only $184 \mathrm{~km}^{2}$ in size, describes a very unique and clearly classified lowland forest habitat within the UMNP which is not found outside the park boundaries and hence shows no evident similar area in the surroundings.

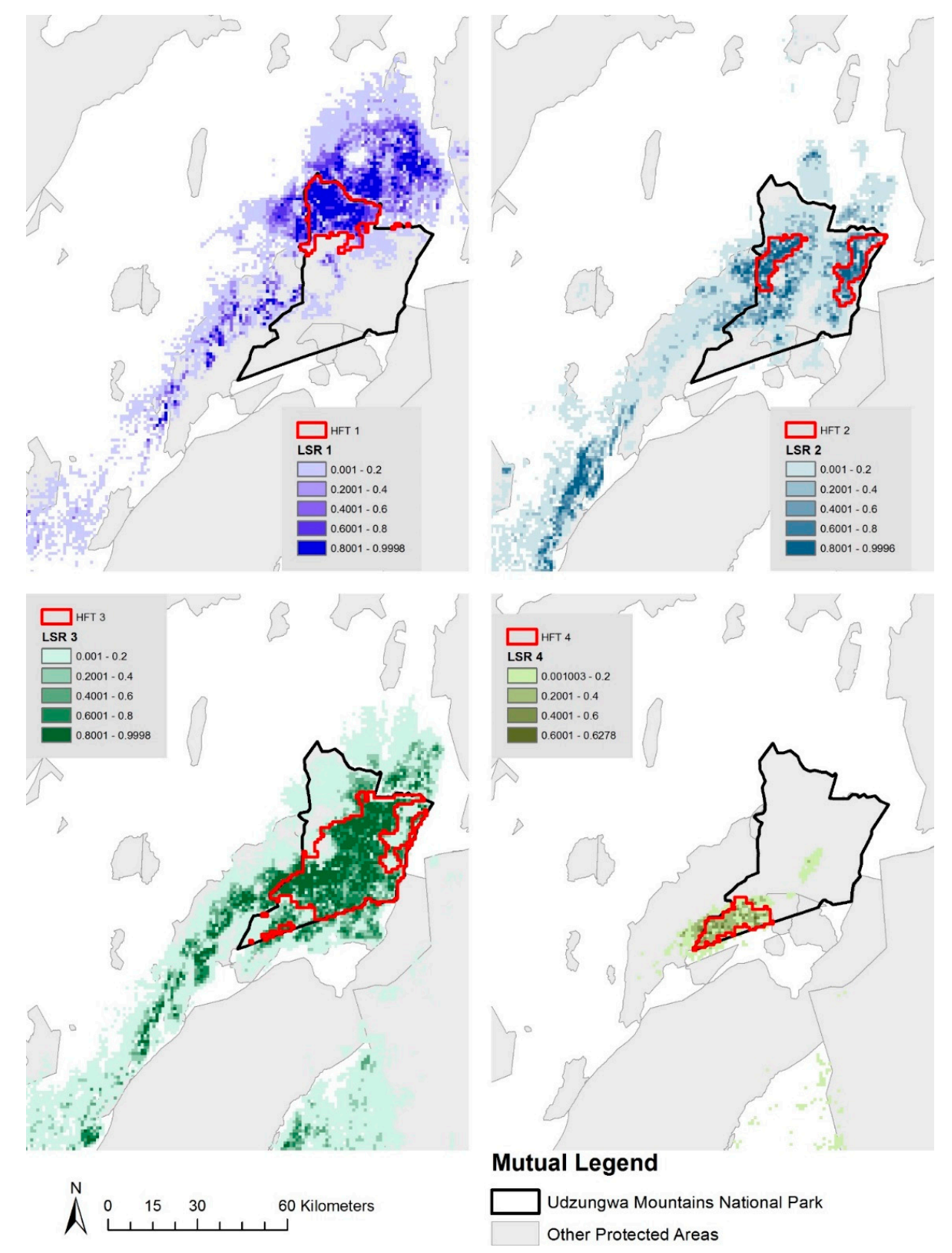

Figure 7. Boundaries of the 4 Habitat Functional Types (HFT) delineated in red and their associated maps of landscape similarities where each pixel is assigned a value where $1=$ high and $0=$ no similarity with the area. The similarity maps are used to derive the Landscape Similarity Ratio (LSR) for each HFT. 


\section{Discussion}

The LULCC analysis shows that the interior of the UMNP has not suffered from relevant human activities during the study period. Some touristic activities have developed inside the park (e.g., trekking routes) but these do not show any major damage or threat to the conservation of the park and its biodiversity [24]. The proximity of settlements surrounding PAs is often associated with timber cutting, pole cutting, fuel wood and wood harvesting and agriculture encroachment [52] inside PAs. However this is not the case for the UMNP as no significant disturbance along the border of the PA has been detected by the proposed methodology. As shown, the natural vegetation which covers around $93 \%$ of the UMNP remained nearly stable at $1780 \mathrm{~km}^{2}$. Fire occurs regularly in the central and northern parts of the park in the period between September till November [53]. These areas belong to the HFTs 1 and 3, which show a strong dominance of grass- and wood and shrublands. The regularity of these fire regimes, associated with no evident change or degradation of the natural vegetation cover, may lead to the assumption that these are prescribed fires to control and maintain the different habitats and the associated plant and animal species. Indeed, in many PAs fire is recognized as playing a key role in the well-being of the biological community (plants and animals) and is included in the park management plans to achieve conservation objectives [54].

The mountainous topography makes this region less accessible for agriculture development, but presumably an effective park management is in place to protect the UMNP's unique habitat and species, as described by WWF and TANAPA [55,56]. However, in the surrounding areas, especially the areas included in the Kilombero Valley Floodplain, where the Udzungwa-Selous corridors (Ruipa and Mwanihana corridors) are located, anthropogenic impact has been strong. Population increase, followed by urban and infrastructure development and a massive agriculture expansion as demonstrated by the analysis, has put severe pressure on the park and the connecting corridors (interesting to note is that the majority of this area is designated as RAMSAR site). In total around $1091 \mathrm{~km}^{2}$ of natural vegetation was converted to agriculture and other anthropogenic land uses in the $20 \mathrm{~km}$ buffer zone over the analyzed 20 year time frame, removing a large proportion of the natural vegetation in the above mentioned corridors. In fact, previous studies demonstrate that the Udzungwa-Selous corridors are currently closed-in particular for elephants [57]. The HFT 3 map presented in Figure 7 confirms this, clearly showing a similar habitat towards the Selous Game Reserve which however is not connected anymore to the UMNP due to the above illustrated land cover changes. Jones, et al. (2012) noted that increased farming and livestock keeping, associated with both local immigration and population growth, were the main reasons for these corridor blockage and closure. However, the authors highlight also the fact that continued attempts by elephants to cross the blocked routes suggest that connectivity can be restored.

Here the analysis of the HFTs and the similarity maps confirmed on the one hand the importance of these corridors for wildlife movements and their uniqueness based on the similarity maps. On the other hand, the similarity maps detected other potential corridors for wildlife as well. The 4 HFTs identified showed that several areas were similar according to their biophysical variables, thus identifying other habitats with suitable characteristics for hosting migrating wildlife such as elephants and which could act as potential corridors. The LULCC analysis showed whether these suitable identified areas are affected by land cover change. This is critical since in particular patterns of agricultural expansion with a consequent loss of natural areas often create "hard edges which inhibits many organisms from readily moving across the edge" [58]. The integration of the LULC map with the HFTs provides a comprehensive habitat map of the type that is regularly requested by the conservation community [59]. LULC associated to bio-physical variables such as vegetation indices, altitude, slope and climatic data delivers the type of information required for the classification and delineation of habitats, which can then be related to specific species and communities.

The importance in maintaining connectivity between PAs has been recognized as a vital element of overall animal population persistence [60,61]. The African continent has suffered from a severe loss and fragmentation of natural vegetation over the last 20 years [62] with a consequent decline 
of natural habitats and increased and unprecedented threat to wildlife [63]. In this context, the role of African PAs in maintaining connectivity in a network is critical. At a continental scale Wegmann, et al. (2016) [64] explain how ecological spatial modelling can be combined with large-scale remote sensing data to investigate land cover changes and their impact on ecological processes and species conservation. In this case, the low resolution Advanced Very High-Resolution Radiometer (AVHRR) Normalized Difference Vegetation Index (NDVI) was used as an indicator for land cover dynamics (i.e., functional properties). Unlike the work presented here, the Wegmann study explicitly models animal movement by simulating steps based on dispersal and perceptual distance for a selected group of species across a landscape. This approach helps to identify the importance of particular pixels and PAs in maintaining connectivity in a landscape, but, because of the continental scale of the analysis, larger pixels (10 km as opposed to $30 \mathrm{~m}$ ) are used to identify vegetation change, so that patterns and disturbances at a rather different scale are being identified. A key difference between the approaches is that the Wegmann study indirectly uses multivariate data to model habitat suitability for selected species (because it uses data from the Rondinini et al. (2011) [65] analysis which combines LULC from the Globcover product [66], elevation and hydrological features) while eHabitat, in contrast, models and maps the similarity between functional habitat types themselves, using a wider range of biophysical variables including climate and evapotranspiration. In future work, the movement simulation approach used in the Wegmann study could valuably be combined with the finer-scale LULCC change information and similarity maps produced in our study.

A valuable summary and review paper highlighting the remote sensing advantages and capabilities for biodiversity monitoring is provided by Petrou, et al. (2015) [67]. The authors present the Aichi targets and the related CBD indicators whose monitoring can be facilitated by remote sensing highlighting for each headline indicator a number of recent remote sensing approaches able for the extraction of related properties. Indeed the general framework of the study presented here could serve several Aichi targets such as target 5, 7, 10 and 11 in particular.

The consistent results of the HFT-LSR and LULCC analysis presented in this study show the usefulness of both methods for assessing and evaluating the territory in relation to the definition of areas of interest for wildlife movements, as well as the impact of human activities in these habitats. The integration of more recent satellite data to describe the actual habitats, but even more importantly to identify current LULCC, is a necessary next step to provide relevant information to decision makers. Indeed, the most recent images provided by Google Earth highlight the fact that the former existing Mngeta forest corridor between the UMNP and the Udzungwa Scarp Forest Reserve is now disrupted by agriculture activities. Field work is additionally required to confirm (or not) the value and nature of the remotely-identified similar habitats and potential corridors and to assess their intactness, presence or absence of human activities and animal movement. Regarding eHabitat+, further work is required to optimize the selection of the input variables and to better understand the links of the HFTs with the species composition in order to further extend its use for policy support.

The results serve as an example of how eHabitat+ allows for large-scale analyses of PAs using continent-wide consistent datasets for producing key landscape indicators, identifying unique ecological areas that are currently unprotected and allowing results to be easily compared at global level through the DOPA $[7,17]$. Moreover, the integrative analysis of these habitat data with accurate LULCC information as derived from the IMPACT toolbox, allows potential pressures on ecological high value areas to be highlighted and thus serves as an effective decision support instrument.

Finally, for a complete and future outlook this information should be analysed in combination with climate change projections for the area. In fact, according to the average over multiple Global Circulation Models (GCMs) in the next 60 years the temperature is likely to rise up to approximately 2 degrees Celsius and rainfall is expected to rise by nearly $50 \mathrm{~mm}$ [68] in the UMNP area. In particular, an increase in temperature may cause the displacement or even disappearance of suitable habitats for some specialised species (see Figure B2 in the Appendix B). 


\section{Conclusions}

Monitoring protected areas to evaluate the success of conservation management practices and to anticipate future conservation problems is a key priority for habitat and species preservation. Moreover, PA specific monitoring tools are relevant for the Convention on Biological Diversity (CBD)'s Strategic Action Plan including the Aichi Biodiversity Targets. However monitoring of sites has to go beyond park boundaries in order to identify and maintain habitat corridors and assess human pressure surrounding sites of conservation importance.

The integration of results from the eHabitat+ tool provided through DOPA with LULCC monitoring as provided through the IMPACT tool, allows assessment of potentially any park by discriminating its different habitats, identifying similar habitats and corridors outside the park and by monitoring the status and the potential pressure on these habitats as derived from LULCC analysis. Development projects such as the SAGCOT "Agriculture Green Growth" initiative in this specific case could take advantage of the integrated habitat and LULC monitoring approaches proposed by this study and implement these in their strategies in order to meet their goal to "sustainably intensify agriculture while simultaneously conserving the natural resources reducing pressures on forest, water and biodiversity [13]". The new EU strategy for wildlife conservation in Africa, which is focusing on key conservation landscapes [69] rather than on individual, independent protected areas, is a first signal and key step towards such a common human-wildlife strategy.

Acknowledgments: The study was accomplished within the framework of the BIOPAMA (Biodiversity and Protected Areas Management) project, a four year initiative (2012-2016) funded by resources from the intra-ACP (African, Caribbean and Pacific) envelope of the 10th European Development Fund (EDF). BIOPAMA aims to address threats to biodiversity in the ACP countries, while reducing poverty in communities in and around protected areas [70]. It is also the first step towards supporting a new European Union (EU) strategy for wildlife conservation in Africa, focusing on key conservation landscapes [69] rather than on individual, independent protected areas. The authors would like to thank Steven R. Schill, senior scientist at the Nature Conservancy, for his constructive and concrete comments and suggestions. His recommendations were very helpful to improve the manuscript. Finally, we would like to thank the anonymous reviewers; their comments improved the manuscript significantly.

Author Contributions: Andreas B. Brink, supervised the project and wrote the paper; Javier Martínez-López, processed the HFTs and LSR and contributed to the writing; Zoltan Szantoi, developed the land use/cover change (LULCC) methodology and contributed to the writing; Pablo Moreno-Atencia, produced the land use/cover change (LULCC) maps and the associated statistics, collected data and information and contributed to the writing; Andrea Lupi, supervised the validation and quality control of the land use/cover change (LULCC) maps; Lucy Bastin, supported the modeling and work on DOPA and contributed to the writing; Grégoire Dubois, supervised the modeling and DOPA contribution and contributed to the writing.

Conflicts of Interest: The authors declare no conflict of interest.

\section{Appendix A}

\section{Tools}

eHabitat+ is based on several Python libraries for multivariate analysis, such as NumPy, SciPy, Scikit-learn, as well as on GRASS GIS 7 for the automatic segmentation of image (Neteler et al. 2012) and its source code is published and available online [18,30].

DOPA Explorer 1.0 provides simple means to explore protected areas, identify those with most unique ecosystems and species composition and assess the pressures they are exposed to through human development [7]. It is available from http://dopa-explorer.jrc.ec.europa.eu/dopa_explorer/.

The satellite IMagery ProCessing Toolbox (v1.2b), IMPACT is an open source system available at http: / / forobs.jrc.ec.europa.eu/products/software/. 


\section{Appendix B}

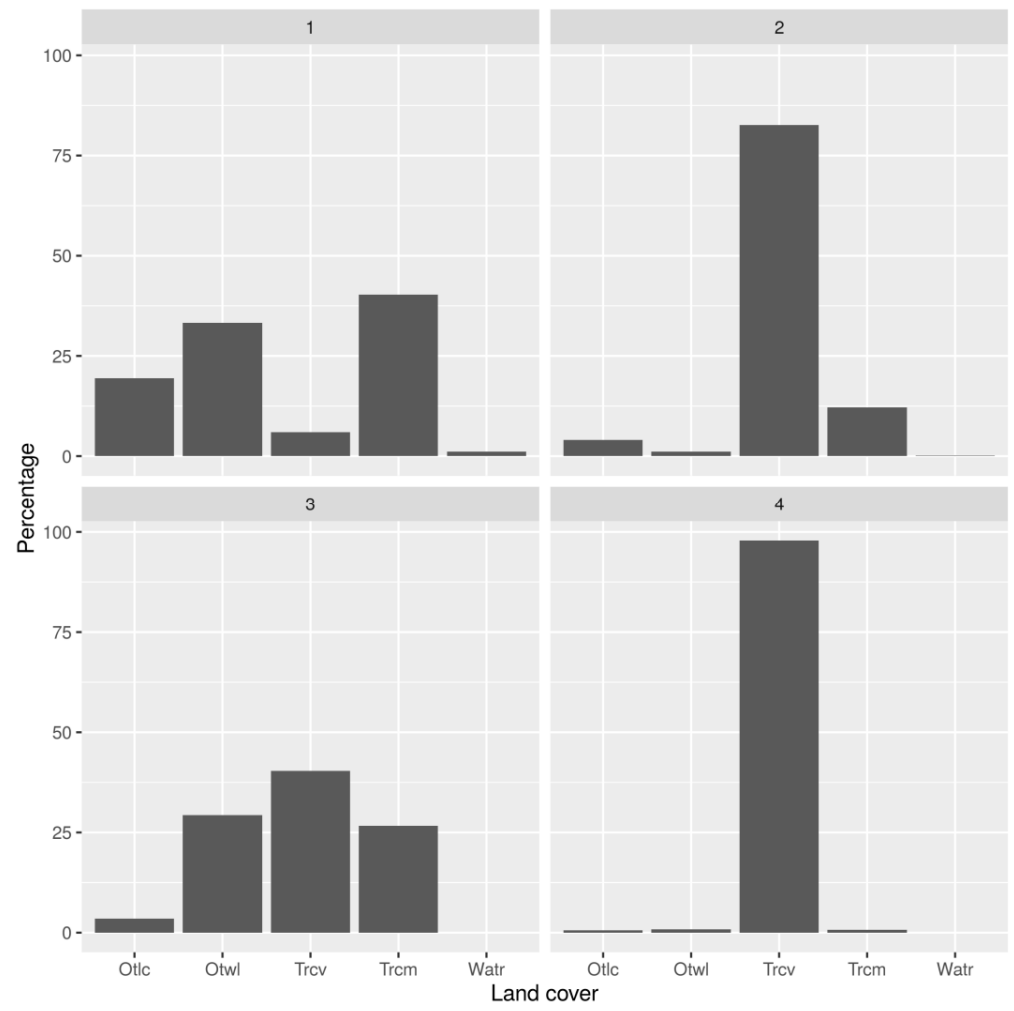

Figure B1. Percentages of land use/land cover (LULC) within each Habitat Functional Type (HFT) in the PA. Legend: Tree cover (Trcv); other land cover (Otlc); Tree cover mosaic (Trcm); water (Watr). Overall, the characterization of each HFT is in agreement with the results obtained from the independent LULC dataset during the study period.

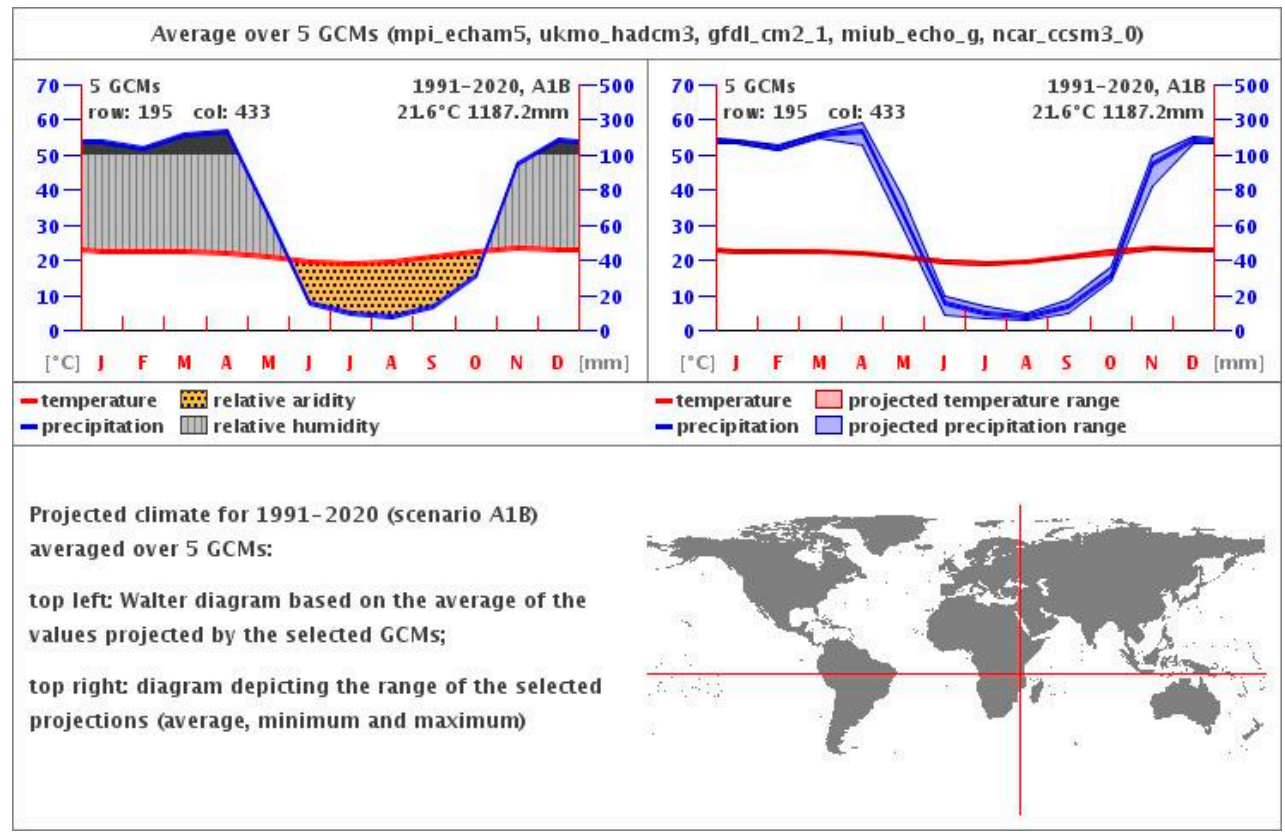

(a)

Figure B2. Cont. 


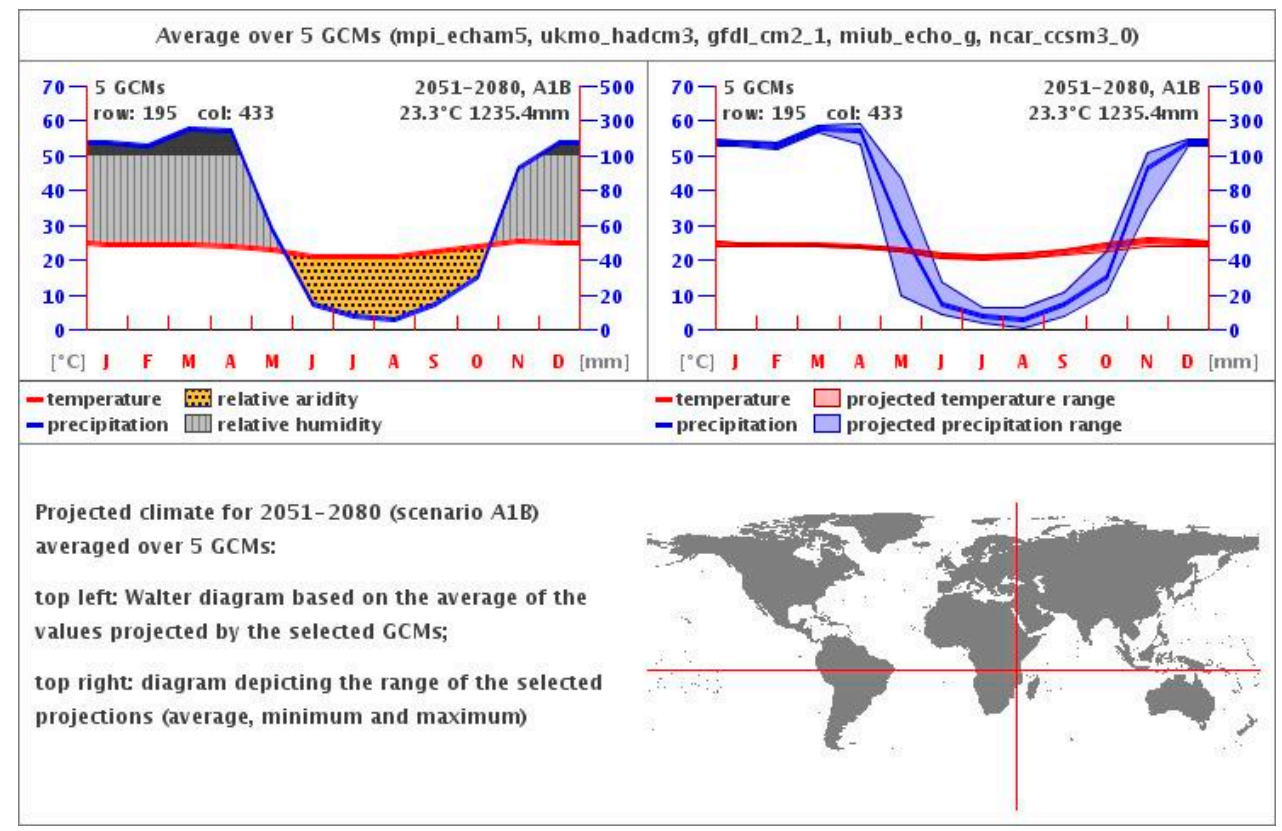

(b)

Figure B2. Projected climate for the UMNP for the period 1991-2020 (a) averaged over 5 Global Circulation Models (GCMs) on top and for the period 2051-2080 (b) at the bottom.

\section{References}

1. Secretariat of the Convention on Biological Diversity (SCBD). COP 10 Decision X/2: Strategic Plan for Biodiversity 2011-2020; Secretariat of the Convention on Biological Diversity: Nagoya, Japan, 2010.

2. Rands, M.R.W.; Adams, W.M.; Bennun, L.; Butchart, S.H.M.; Clements, A.; Coomes, D.; Entwistle, A.; Hodge, I.; Kapos, V.; Scharlemann, J.P.W.; et al. Biodiversity Conservation: Challenges Beyond 2010. Science 2010, 329, 1298-1303. [CrossRef] [PubMed]

3. Juffe-Bignoli, D.; Burgess, N.D.; Bingham, H.; Belle, E.M.S.; de Lima, M.G.; Deguignet, M.; Bertzky, B.; Milam, A.N.; Martinez-Lopez, J.; Lewis, E.; et al. Protected Planet Report 2014; United Nations Environment Program-World Conservation Monitoring Center (UNEP-WCMC): Cambridge, UK, 2014.

4. Keith, D.A.; Rodríguez, J.P.; Rodríguez-Clark, K.M.; Nicholson, E.; Aapala, K.; Alonso, A.; Asmussen, M.; Bachman, S.; Basset, A.; Barrow, E.G.; et al. Scientific Foundations for an IUCN Red List of Ecosystems. PLoS ONE 2013, 8, e62111. [CrossRef] [PubMed]

5. Stuart, S.N.; Adams, R.J.; Jenkins, M.D. Biodiversity in Sub-Saharan Africa and Its Islands; International Union for Conservation of Nature (IUCN): Gland, Switzerland, 1990.

6. Byers, B.; Aloyce, Z.; Munishi, P.; Rhoades, C. Tanzania Environmental Threats and Opportunities Assessment; United States Agency for International Development (USAID): Dar es Salaam, Tanzania, 2012.

7. Dubois, G.; Bastin, L.; Martinez-Lopez, J.; Cottam, A.; Temperley, H.; Bertzky, B.; Graziano, M. The Digital Observatory for Protected Areas (DOPA) Explorer 1.0; EUR 27162 EN; Publications Office of the European Union: Luxembourg, 2015; p. 53.

8. Jones, T.; Caro, T.; Davenport, T.R.B. Wildlife Corridors in Tanzania; Unpublished Report; Tanzania Wildlife Research Institute (TAWIRI): Arusha, Tanzania, 2009.

9. Bamford, A.; Ferrol-Schulte, D. The Status of the Nyanganje Wildlife Corridor (Udzungwas to Selous) during the Rainy Season of 2010; Report to Frontier Tanzania; WWF-Tanzania Programme Office: Dar es Salaam, Tanzania, 2010.

10. Bamford, A.; Ferrol-Schulte, D.; Smith, H. The Status of the Ruipa Corridor between the Selous Game Reserve and the Udzungwa Mountains; Report to Frontier Tanzania; WWF-Tanzania Programme Office: Dar es Salaam, Tanzania, 2010. 
11. Hieronimo, P.; Jones, T.; Rovero, F. Conserving the Nyanganje Wildlife Corridor (Udzungwa-Selous), Phase I; Final Report to WWF-Tanzania Programme Office; WWF-Tanzania Programme Office: Dar esSalaam, Tanzania, 2010.

12. United Nations, Department of Economic and Social Affairs, Population Division. World Population Prospects: The 2012 Revision, Highlights and Advance Tables. Available online: https:/ /esa.un.org/unpd/ wpp/publications/Files/WPP2012_HIGHLIGHTS.pdf (accessed on 27 May 2016).

13. Milder, J.C.; Hart, A.K.; Buck, L.E. Applying an Agriculture Green Growth Approach in the SAGCOT Clusters: Challenges and Opportunities in Kilombero, Ihemi and Mbarali; SAGCOT Centre: Dar es Salaam, Tanzania, 2013.

14. Buchanan, G.M.; Nelson, A.; Mayaux, P.; Hartley, A.; Donald, P.F. Delivering a Global, Terrestrial, Biodiversity Observation System through Remote Sensing. Conserv. Biol. 2009, 23, 499-502. [CrossRef] [PubMed]

15. Nagendra, H.; Lucas, R.; Pradinho Honradoc, J.; Jongman, R.H.G.; Tarantino, C.; Adamo, M.; Mairota, P. Remote sensing for conservation monitoring: Assessing protected areas, habitat extent, habitat condition, species diversity, and threats. Ecol. Indic. 2013, 33, 45-59. [CrossRef]

16. Beresford, A.E.; Eshiamwata, G.W.; Donald, P.F.; Balmford, A.; Bertzky, B.; Brink, A.B.; Fishpool, L.D.C.; Mayaux, P.; Phalan, B.; Simonetti, D.; et al. Protection Reduces Loss of Natural Land-Cover at Sites of Conservation Importance across Africa. PLoS ONE 2013, 8, e65370. [CrossRef] [PubMed]

17. Dubois, G.; Schulz, M.; Skøien, J.; Bastin, L.; Peedell, S. eHabitat, a Multi-Purpose Web Processing Service for Ecological Modeling. Environ. Model. Softw. 2013, 41, 123-133. [CrossRef]

18. Martínez-López, J.; Bertzky, B.; Bonet-García, F.J.; Bastin, L.; Dubois, G. Biophysical Characterization of Protected Areas Globally through Optimized Image Segmentation and Classification. Remote Sens. 2016, 8, 780. [CrossRef]

19. Szantoi, Z.; Brink, A.; Buchanan, G.; Bastin, L.; Lupi, A.; Simonetti, D.; Mayaux, P.; Peedell, S.; Davy, J. A simple remote sensing based information system for monitoring sites of conservation importance. Remote Sens. Ecol. Conserv. 2016, 2, 16-24. [CrossRef]

20. IUCN; UNEP-WCMC. The World Database on Protected Areas (WDPA), version 2016; UNEP-WCMC: Cambridge, UK, 2016. Available online: http:/ /www.protectedplanet.net (accessed on 17 August 2016).

21. Rovero, F.; Marshall, A.R.; Jones, T.; Perkin, A. The primates of the Udzungwa Mountains: Diversity, ecology and conservation. J. Anthropol. Sci. 2009, 87, 93-126. [PubMed]

22. Olson, D.M.; Dinerstein, E.; Wikramanayake, E.D.; Burgess, N.D.; Powell, G.V.N.; Underwood, E.C.; Kassem, K.R. Terrestrial Ecoregions of the World: A New Map of Life on Earth: A new global map of terrestrial ecoregions provides an innovative tool for conserving biodiversity. BioScience 2001, 51, $933-938$. [CrossRef]

23. Burgess, N.D.; Butynski, T.M.; Cordeiro, N.J.; Doggart, N.H.; Fjeldsa, J.; Howell, K.M.; Kilahama, F.B.; Loader, S.P.; Lovett, J.C.; Mbilinyi, B.; et al. The biological importance of the eastern Arc Mountains of Tanzania and Kenya. Biol. Conserv. 2007, 134, 209-231. [CrossRef]

24. Rovero, F.; Struhsaker, T.T.; Marshall, A.R.; Rinne, T.A.; Pedersen, U.B.; Butynski, T.M.; Ehardt, C.L.; Mtui, A.S. Abundance of Diurnal Primates in Mwanihana Forest, Udzungwa Mountains, Tanzania. Int. J. Primatol. 2006, 27, 675. [CrossRef]

25. IUCN 2016. The IUCN Red List of Threatened Species. Version 2016-1. Available online: http:/ / www.iucnredlist. org (accessed on 18 August 2016).

26. RAMSAR. Convention on Wetlands. 2016. Available online: http://www.ramsar.org/ (accessed on 17 August 2016).

27. Tanzania Wildlife Research Institute (TAWIRI). Elephant Population Estimate in Tanzania, Dry Season; Tanzania Wildlife Research Institute: Arusha, Tanzania, 2009.

28. Simonetti, D.; Marelli, A.; Eva, H.D. IMPACT: Portable GIS Toolbox for Image Processing and Land Cover Mapping; EUR 27358 EN; Scientific and Technical Research Series; Publications Office of the European Union: Luxembourg, 2015.

29. Paruelo, J.M.; Piñeiro, G.; Escribano, P.; Oyonarte, C.; Alcaraz, D.; Cabello, J. Temporal and spatial patterns of ecosystem functioning in protected arid areas in southeastern Spain. Appl. Veg. Sci. 2005, 8, 93-102. [CrossRef]

30. Martínez-López, J. eHabitat+ source code for DOPA. Zenodo 2016. [CrossRef] 
31. DiMiceli, C.M.; Carroll, M.L.; Sohlberg, R.A.; Huang, C.; Hansen, M.C.; Townshend, J.R.G. Annual Global Automated MODIS Vegetation Continuous Fields (MOD44B) at $250 \mathrm{~m}$ Spatial Resolution for Data Years Beginning Day 65, 2000-2010, Collection 5 Percent Tree Cover; University of Maryland: College Park, MD, USA, 2011.

32. US Geological Survey (USGS). Shuttle Radar Topography Mission, 1 Arc Second Scene SRTM_u03_n008e004; University of Maryland: College Park, MD, USA, 2000.

33. Hijmans, R.; Cameron, S.E.; Parra, J.L.; Jones, P.G.; Jarvis, A. Very high resolution interpolated climate surfaces for global land areas. Int. J. Climatol. 2005, 25, 1965-1978. [CrossRef]

34. Carroll, M.L.; DiMiceli, C.M.; Sohlberg, R.A.; Townshend, J.R.G. 250 m MODIS Normalized Difference Vegetation Index, 250ndvi28920033435, Collection 4; University of Maryland: College Park, MD, USA, 2014.

35. Justice, C.O.; Townshend, J.R.G.; Holben, B.N.; Tucker, C.J. Analysis of the phenology of global vegetation using meteorological satellite data. Int. J. Remote Sens. 1985, 6, 1271-1318. [CrossRef]

36. Carroll, M.; Townshend, J.; DiMiceli, C.; Noojipady, P.; Sohlberg, R. A New Global Raster Water Mask at $250 \mathrm{~m}$ Resolution. Int. J. Digit. Earth 2009, 2, 291-308. [CrossRef]

37. Ceccato, P.; Flassee, S.; Tarantola, S.; Jacquemoud, S.; Gregoire, J.-M. Detecting vegetation leaf water content using reflectance in the optical domain. Remote Sens. Environ. 2001, 77, 22-33. [CrossRef]

38. Adams, R.; Bischof, L. Seeded region growing. IEEE Trans. Pattern Anal. Mach. Intell. 1994, 16, $641-647$. [CrossRef]

39. Pérez-Hoyos, A.; Martínez, B.; García-Haro, F.J.; Moreno, Á.; Gilabert, M.A. Identification of Ecosystem Functional Types from Coarse Resolution Imagery Using a Self-Organizing Map Approach: A Case Study for Spain. Remote Sens. 2014, 6, 11391-11419. [CrossRef]

40. Mahalanobis, P.C. On the generalized distance in statistics. Proc. Nat. Inst. Sci. India 1936, 12, 49-55.

41. Bodart, C.; Eva, H.; Beuchle, R.; Rasi, R.; Simonetti, D.; Stibig, H.-J.; Brink, A.; Lindquist, E.; Achard, F. Pre-processing of a sample of multi-scene and multi-date Landsat imagery used to monitor forest cover changes over the tropics. ISPRS J. Photogramm. Remote Sens. 2011, 66, 555-563. [CrossRef]

42. Szantoi, Z.; Simonetti, D. Fast and robust topographic correction method for medium resolution satellite imagery using a stratified approach. IEEE J. Sel. Top. Appl. Earth Obs. Remote Sens. 2013, 6, 1921-1933. [CrossRef]

43. Song, C.; Woodcock, C.E.; Seto, K.C.; Lenney, M.P.; Macomber, S.A. Classification and change detection using Landsat TM data: When and how to correct atmospheric effects. Remote Sens. Environ. 2001, 75, 230-244. [CrossRef]

44. Hansen, M.; Roy, D.; Lindquist, E.; Adusei, B.; Justice, C.; Altstatt, A. A method for integrating MODIS and Landsat data for systematic monitoring of forest cover and change in the Congo Basin. Remote Sens. Environ. 2008, 112, 2495-2513. [CrossRef]

45. Baatz, M.; Schäpe, A. Multiresolution segmentation: An optimization approach for high quality multi-scale image segmentation. In XII Angewandte Geographische Informationsverarbeitung; Wichmann: Heidelberg, Germany, 2000.

46. Câmara, G.; Vinhas, L.; Ferreira, K.; Queiroz, G.; Souza, R. TerraLib: An open source GIS library for largescale environmental and socio-economic applications. In Open Source Approaches in Spatial Data Handling; Springer: Berlin/Heidelberg, Germany, 2008; pp. 247-270.

47. Rasi, R.; Bodart, C.; Stibig, H.-J.; Eva, H.; Beuchle, R.; Carboni, S.; Simonetti, D.; Achard, F. An automated approach for segmenting and classifying a large sample of multi-date Landsat imagery for pan-tropical forest monitoring. Remote Sens. Environ. 2011, 115, 3659-3669. [CrossRef]

48. OpenStreetMap Contributors. 2016. Available online: http://www.openstreetmap.org (accessed on 17 August 2016).

49. Struhsaker, T.T.; Marshall, A.R.; Detwiler, K.; Siex, K.; Ehardt, C.; Lisbjerg, D.D.; Butynski, T.M. Demographic Variation Among Udzungwa Red Colobus in Relation to Gross Ecological and Sociological Parameters. Int. J. Primatol. 2004, 25, 615-658. [CrossRef]

50. Madulu, N.F. Population Distribution and Density in Tanzania: Experiences from 2002 Population and Housing Census. Available online: http://ccs.ukzn.ac.za/files/madulu.pdf (accessed on 14 September 2016).

51. Struhsaker, T.T. Conservation of Red Colobus and Their Habitats. Int. J. Primatol. 2005, 26, 525-538. [CrossRef]

52. Harrison, P. Incorporating Livelihood Assessments and Options forFuture Management of Udzungwa Forests; WWF-Tanzania Programme Office: Dar es Salaam, Tanzania, 2006. 
53. Fire Monitoring Tool, Joint Research Centre, European Commission. Available online: http://firetool.jrc.ec. europa.eu/ (accessed on 24 August 2016).

54. Myers, R.L. Living with Fire: Sustaining Ecosystems and Livelihoods through Integrated Fire Management; Global Fire Initiative; The Nature Conservancy: Arlington County, VA, USA, 2006.

55. WWF-Udzungwa Mountains National Park, Tanzania Project. Available online: http://wwf.panda.org/ who_we_are/wwf_offices/tanzania/index.cfm?uProjectID=TZ0044 (accessed on 6 May 2016).

56. TANAPA. Tanzania National Parks. Available online: http://www.tanzaniaparks.go.tz/ (accessed on 6 May 2016).

57. Jones, T.; Bamford, A.J.; Ferrol-Schulte, D.; Hieronimo, P.; McWilliam, N.; Rovero, F. Vanishing wildlife corridors and options for restoration: A case study from Tanzania. Trop. Conserv. Sci. 2012, 5, 463-474. [CrossRef]

58. Bennet, A.F. Linkages in the Landscape: The Role of Corridors and Connectivity in Wildlife Conservation; World Conservation Union: Gland, Switzerland, 2003.

59. Green, R.E.; Buchanan, G.M.; Almond, R. What Do Conservation Practitioners Want from Remote Sensing? Available online: http//www.conservation.cam.ac.uk/resource/working-papers-and-reports/ccireportwhat-do-conservation-practitioners-want-remote (accessed on 27 May 2016).

60. Fahrig, L.; Merriam, G. Habitat patch connectivity and population survival. Ecology 1985, 66, $1762-1768$. [CrossRef]

61. Kool, J.T.; Moilanen, A.; Treml, E.A. Population connectivity: Recent advances and new perspectives. Landsc. Ecol. 2012, 28, 165-185. [CrossRef]

62. Achard, F.; Beuchle, R.; Mayaux, P.; Stibig, H.-J.; Bodart, C.; Brink, A.; Carboni, S.; Desclée, B.; Donnay, F.; Eva, H.D.; et al. Determination of tropical deforestation rates and related carbon losses from 1990 to 2010. Glob. Chang. Biol. 2014, 20, 2540-2554. [CrossRef] [PubMed]

63. Newmark, W.D. Isolation of African protected areas. Front. Ecol. Environ. 2008, 6, 321-328. [CrossRef]

64. Wegmann, M.; Santini, L.; Leutner, B.; Safi, K.; Rocchini, D.; Bevanda, M.; Latifi, H.; Dech, S.; Rondinini, C. Role of African protected areas in maintaining connectivity for large mammals. Philos. Trans. R. Soc. B 2014, 369, 20130193. [CrossRef] [PubMed]

65. Rondinini, C.; Di Marco, M.; Chiozza, F.; Santulli, G.; Baisero, D.; Visconti, P.; Hoffmann, M.; Schipper, J.; Stuart, S.N.; Tognelli, M.F.; et al. Global habitat suitability models of terrestrial mammals. Philos. Trans. R. Soc. B Biol. Sci. 2011, 366, 2633-2641. [CrossRef] [PubMed]

66. Arino, O.; Ramos, P.; Jose, J.; Kalogirou, V.; Bontemps, S.; Defourny, P.; Van Bogaert, E. Global Land Cover Map for 2009 (GlobCover 2009); PANGAEA-Data Publisher for Earth \& Environmental Science: Bremen, Germany, 2012. [CrossRef]

67. Petrou, Z.I.; Manakos, I.; Stathaki, T. Remote sensing for biodiversity monitoring: A review of methods for biodiversity indicator extraction and assessment of progress towards international targets. Biodivers. Conserv. 2015, 24, 2333-2363. [CrossRef]

68. Climate Impacts: Global and Regional Adaptation Support Platform. Available online: http://cigrasp.pikpotsdam.de/diagrams/average (accessed on 7 August 2016).

69. European Commission. Larger than Elephants Inputs for the Design of an EU Strategic Approach to Wildlife Conservation in Africa-Synthesis; Publications Office of the European Union: Luxembourg, 2015.

70. BIOPAMA. Biodiversity and Protected Areas Management Programme. Available online: http://www. biopama.org (accessed on 17 August 2016).

(C) 2016 by the authors; licensee MDPI, Basel, Switzerland. This article is an open access article distributed under the terms and conditions of the Creative Commons Attribution (CC-BY) license (http://creativecommons.org/licenses/by/4.0/). 